Vol.45, N. 2 : pp. 177 - 182, June 2002

ISSN 1516-8913 Printed in Brazil

\title{
Changes in Electrophoretic Profiles of Ipomoea batatas (Sweet Potato) Induced by Gamma Radiation
}

\author{
Celso Luiz Salgueiro Lage*; Alexandre Guimarães Vasconcellos; Nina Claudia Barboza da \\ Silva and Maria Apparecida Esquibel \\ Laboratório de Fisiologia Vegetal; Instituto de Biofisica Carlos Chagas Filho; Universidade Federal do Rio de \\ Janeiro; CCS; Bloco G; Cidade Universitária; CEP 21941-590; Rio de Janeiro - RJ - Brazil
}

\begin{abstract}
The ability of nodal segments of Ipomoea batatas to differentiate shoots and roots was evaluated after gamma irradiation. Shoot differentiation was less sensitive to irradiation than roots. However, at 90 Gy, no shoot was able to regenerate a new plant; in contrast $76 \%$ of the roots from irradiated nodal segments continued to grow. The gamma radiation also induced changes in electrophoretic profiles of peroxidases of storage roots. Plants originated from irradiated storage roots presented changes in leaf peroxidase profiles very similar to those produced by leaves directly irradiated. The peroxidase profile of absorbent roots from irradiated storage roots was different from that obtained from directly irradiated absorbent roots.
\end{abstract}

Key words: Peroxidases; gamma radiation, sweet potato, Ipomoea batatas, convovulaceae

\section{INTRODUCTION}

Studies on the action of radiation on plant physiology frequently emphasize its direct deleterious effects, mainly on plant hormones (Skoog, 1934, 1935; Momiyama et al., 1999) or their biosynthesis (Gordon, 1957). The loss of reactivity of irradiated cells to a growth-promoting agent has been reported by Miura et al. (1974). In this paper, the effects of gamma radiation on Ipomoea batatas L. Lam (sweet potato) were evaluated in terms of the ability of nodal segments to form shoots and roots. Besides the evaluation of their ability to differentiate shoots and roots, issoperoxidases were analysed electrophoretically. These enzymes play a significant role in plant physiology (Van Huystee and Clarins, 1982; Van
Huystee, 1987) as indicators of resistance and response to injury (Birecka et al., 1973; Birecka and Catafalmo, 1975; Luthra et al., 1988; Reuveni et al., 1992; Barabas et al., 1998; Kubo et al., 1999, Riedle-Bauer, 2000). As a consequence, peroxidases have been used as markers of differentiation in somatic embryogenesis (Joersbo et al., 1989; Hadrami et al., 1989), and leaf and root morphogenesis in barley calli culture, before initiation of the primordium (Coppens and Dewitte, 1990). Changes in plant peroxidases due to treatment with radiation had also been reported as marked increase in peroxidase activity of leaves from plants originated by irradiated nodal segments of sweet potato (Lage and Esquibel, 1997). Absorbent roots grown from irradiated sweet potato storage roots have also a modified

\footnotetext{
* Author for correspondence
} 
electrophoretic profile of isoperoxidases (Lage and Esquibel, 1995).

The objective of the present study was to investigate the radiation effects on shoot and root differentiation, and also evaluate changes in electrophoretic profiles of peroxidases after treatment of $I$. batatas with gamma radiation.

\section{MATERIAL AND METHODS}

\section{Plant material}

Monoclonal plants regenerated from meristem tip culture (Alconero et al., 1975) of Ipomoea batatas L. Lam. cv. Roxinha were used in the experiments. Plantlets were subcultured every 60 days. At each subculture, nodal explants were excised and placed on fresh MS culture medium (Murashige and Skoog, 1962). Nodal explants, each containing a single dormant meristem, were obtained during the micropropagation phase. All cultures were maintained at $25 \pm 2{ }^{\circ} \mathrm{C}$ with an illumination rate of $23 \mu \mathrm{mol} . \mathrm{cm}^{-2} \cdot \mathrm{s}^{-1}$ with a $16-\mathrm{h}$ photoperiod.

Intact, unsprouted monoclonal storage roots collected in the field were selected according to weight, ranging from 250 to $270 \mathrm{~g}$. These storage roots were produced by acclimated plants from in vitro meristem culture (Alconero et al.1975). The meristem-regenerated plants were used to avoid pathogen interference in the results.

\section{Irradiation}

Irradiation treatments were performed according to the method of Lage and Esquibel (1992) using a ${ }^{60} \mathrm{Co}$ source, at a dose rate of $0.44 \mathrm{~Gy} / \mathrm{min}$. Plants were irradiated after 60 days of in vitro culture. Immediately after irradiation, the nodal segments were excised and placed in fresh medium. Three groups of 10 storage roots were prepared. Two of them were irradiated at 90 and $180 \mathrm{~Gy}$ of gamma radiation, respectively, and immediately immersed in water to allow shooting and rooting. The remaining group was left untreated and placed in water. Part of shoots and absorbent roots grown from the untreated group was irradiated to verify the direct effect of radiation in the studied organs. The immersion water was changed at intervals of 3 days in all treatments.

\section{Peroxidase analysis}

The electrophoretic runs were performed on $9.5 \%$ starch gel at $7{ }^{\circ} \mathrm{C}$ for 4 hours, in nine parts of 0.2 $\mathrm{M}$ Tris-citrate buffer, $\mathrm{pH} 8.3$, plus one part $0.2 \mathrm{M}$ lithium-borate, $\mathrm{pH}$ 8.3. The lithium-borate buffer was used as the running buffer (Scandalios, 1969). Samples were applied in the middle of the gel. The gels were developed with $0.2 \mathrm{M}$ sodium acetate buffer, $\mathrm{pH} 5.5$, plus $0.6 \mathrm{ml} 30 \% \mathrm{H}_{2} \mathrm{O}_{2}$ and $20 \mathrm{mg}$ $\%$ 3-amino-9-ethyl-carbazole. The enzymes were extracted by homogenization in $0.1 \mathrm{M}$ potassium phosphate buffer at $0^{\circ} \mathrm{C}$.

\section{Analysis of differentiation patterns}

The nodal explants in vitro were periodically observed during 40 days in culture. The differentiation of shoots and roots was analyzed as percents of newly formed structures relatively to the total number of explants. Means and standard deviations reflect variation within each time that each experiment was conducted.

\section{RESULTS}

\section{Radiation effects on differentiation}

The radiation effects were evaluated in terms of the ability of nodal segments to differentiate shoots and roots. The nodal segments showed a dose-dependent decrease in their ability to differentiate both roots and shoots (Fig. 1). Compared to control plants, the efficiency to form shoots fell to $62 \%$ and the ability to form roots was $20 \%$ at $90 \mathrm{~Gy}$. Although shoot differentiation was less sensitive to irradiation than root differentiation, at $90 \mathrm{~Gy}$ no shoot was able to regenerate a new plant. The differentiated shoots stopped growing in early developmental stages. In contrast, $76 \%$ of the roots originated by the nodal segments irradiated at 90 Gy continued to grow.

A significant delay was found in the differentiation of shoots and roots in irradiated nodal segments, even at the lowest doses applied, and the lag phase increased proportionally with the radiation dose (Fig. 1, A,B,C and D). These results implicated the differentiation of aerial parts to be more strongly determinated than root ones. 

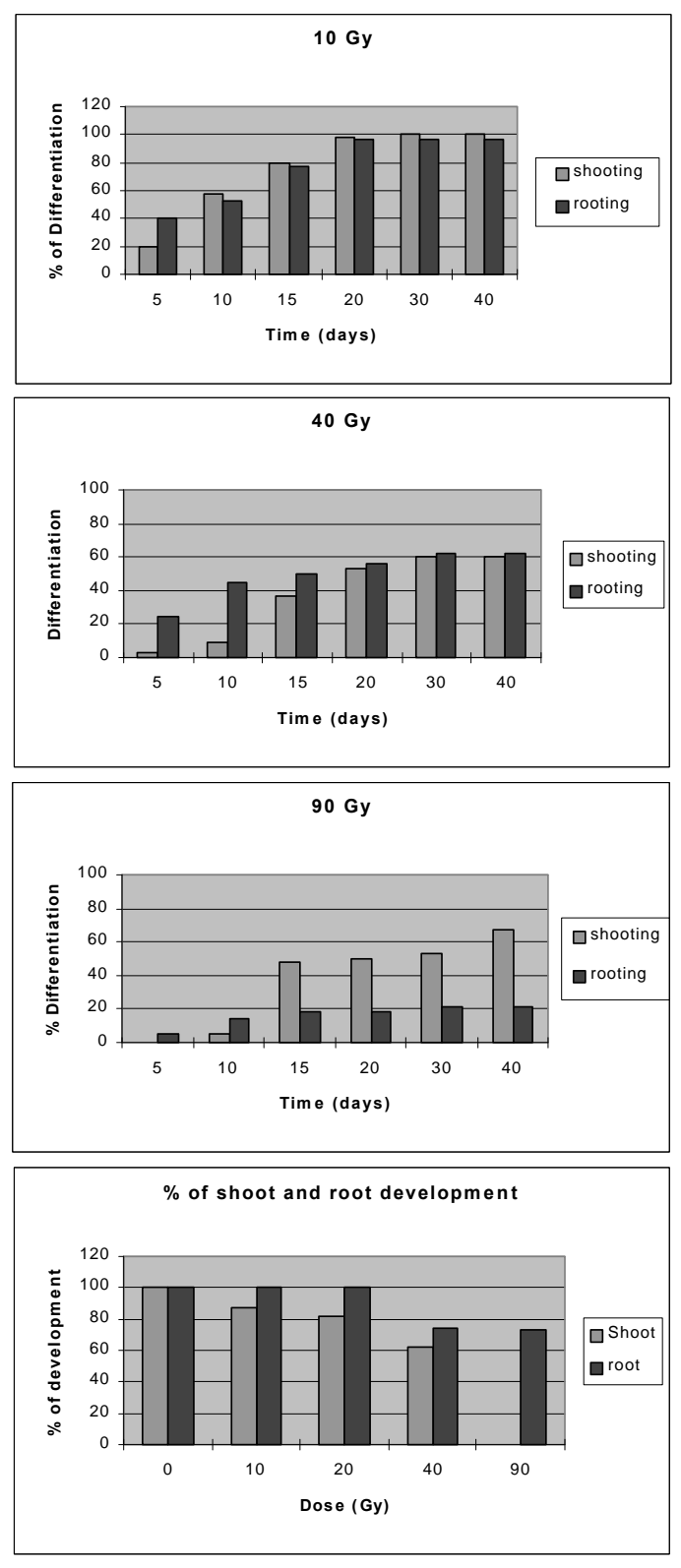

Figure 1 - Effects of several radiation doses on shooting and rooting of $I$. batatas

\section{Electrophoretic profile of peroxidases}

Fig. 2 shows the electrophoretic profiles of peroxidases extracted from leaves of I. batatas cv Roxinha after different treatments. In this figure, the first run from left to right was control, second and third runs were the peroxidase patterns of leaves originated from irradiated storage roots at 90 and $180 \mathrm{~Gy}$, respectively. Finally, the last one presented the peroxidase pattern of leaves directly irradiated with $90 \mathrm{~Gy}$. All radiation treatments caused changes in peroxidase profiles when compared with the control.

It is interesting to observe that the profile of leaves directly irradiated with 90 Gy was very similar to that of leaves of plants originated from storage roots irradiated at $180 \mathrm{~Gy}$. This result implied the gamma radiation as an agent able to induce changes in peroxidases of storage roots that would persist in the leaves of the plants grown from them. Furthermore, the changes in the peroxidase profile persisted during the differentiation process, and it still was present in the leaves of plants originated from the irradiated storage roots. All the radiation treatments also resulted in enhancement of the cathodic bands.

The peroxidase profiles of absorbent roots is presented in Fig. 3. All the radiation treatments resulted in changes in electrophoretic profiles, but differently from what occurred with leaves. The peroxidase pattern found in directly irradiated absorbent roots not similar to those of roots originated from irradiated storage roots. The cathodic bands lost intensity at $90 \mathrm{~Gy}$, while at $180 \mathrm{~Gy}$ an enhancement occur. Similar results were found for cathodic peroxidase profiles of absorbent roots of another cultivar, Paty do Alferes (Fig. 4).

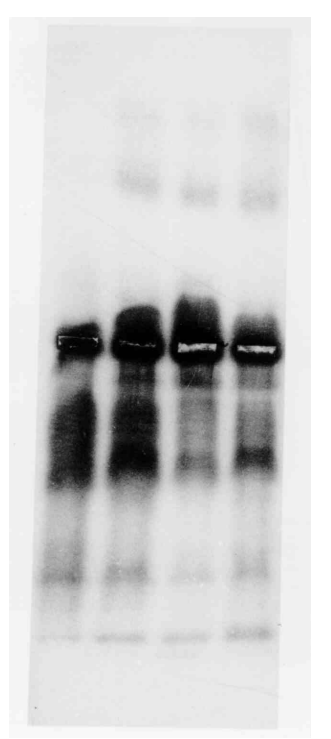

Figure 2 - Electrophoretic profile of isoperoxidases of leaves from roxinha cultivar. From left to right each run shows the profile of leaves grown from storage roots subjected to the following treatments: not treated; irradiated at $90 \mathrm{~Gy}$; irradiated at $180 \mathrm{~Gy}$. The last one presents the profile of leaves directly irradiated at 90 Gy. Cathodic bands are in the upper side of the gel. 


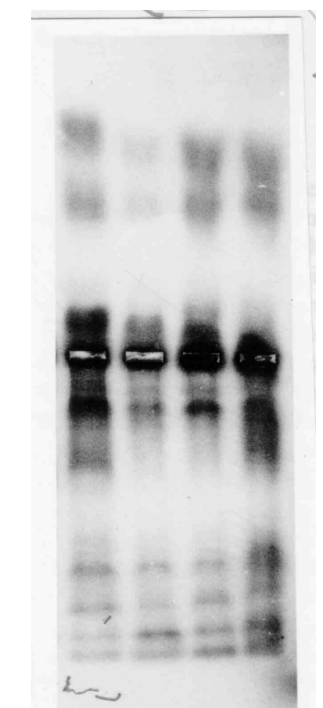

Figure 3 - Electrophoretic profile of isoperoxidases of absorbent roots from roxinha cultivar. From left to right each run shows the profile of absorbent roots grown from storage roots subjected to the following treatments: not treated; irradiated at $90 \mathrm{~Gy}$; irradiated at $180 \mathrm{~Gy}$. The last one presents the profile of absorbent roots directly irradiated at $90 \mathrm{~Gy}$. Cathodic bands are in the upper side of the gel.

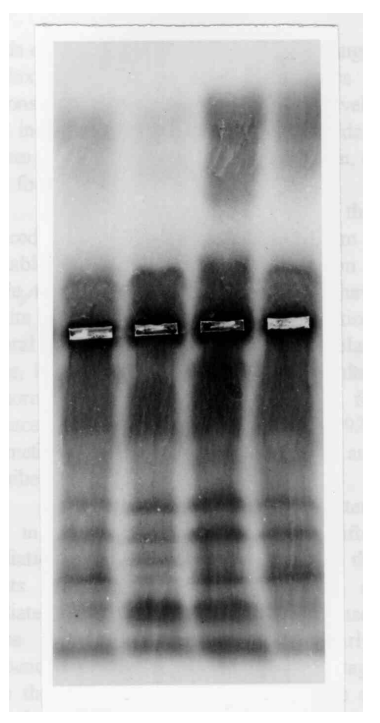

Figure 4 - Electrophoretic profile of isoperoxidases of absorbent roots from Paty do Alferes cultivar. From left to right each run shows the profile of absorbent roots grown from storage roots subjected to the following treatments: not treated; irradiated at $90 \mathrm{~Gy}$; irradiated at with $180 \mathrm{~Gy}$. The last one presents the profile of absorbent roots directly irradiated at $90 \mathrm{~Gy}$. Cathodic bands are in the upper side of the gel.

\section{DISCUSSION}

The first point to discuss are the differences found for both differentiation and peroxidase electrophoretic profiles in shoots and roots taking into account the origin of each one. Shoots are formed from a dormant meristem, a complex structure responsible for the organogenesis in the post-embryonic period, and the leaf primordium destiny is established in an extremely early stage (Steeves and Sussex, 1990a). In contrast, roots differentiate from pericicle cells - one or more layers of cells that constitute the outermost region of the vascular system (Steeves and Sussex, 1990b), where a single cell form an adventitious root meristem differentiates the new root. In the first case, the meristem that originates the aerial part is already formed before the shooting stimulus, and therefore is probably less affected by the radiation treatment. In the second case, the pericicle cells will generate a new meristem, in such a way that its formation could be affected by radiation by interfering with their epigenetic material. Changes in the epigenetic material may be related to permanent phenotypic modifications, defined as somaclonal variation (Larkin and Scrowcroft, 1981), commonly found in adventitiously regenerated plants. Lage and Rocha (1994) as defined by Waddington (1975) considered this phenomenon as an example of genetic assimilation. Changes in peroxidases must have direct effects in IAA turnover (Glaston et al., 1953; Kenten, 1955; Hokkinakis and Brooks, 1979; Acosta et al., 1989; Gazarian et al., 1998; Kubo et al.,1999), therefore affecting phenotype of the regenerated plant. Fields et al. (1989) reported heritable changes in flax peroxidases for two generations in response to modification in nitrogen levels. This indicates that changes in the peroxidase pattern could be maintained over long term, or even for generations.

Considering the possibility that induced changes in the peroxidases pattern is heritable, then a plant regenerated from a single enzymatically modified cell could have all its cells harboring this modification. Several forms of stress when given to plant tissue, in early developmental stages resulted in more vigorous or resistant plants, as, for instance, radiation (Lage and Esquibel, 1992), or methylene blue treatments (Lage and Esquibel, 1997). 
The changes in peroxidase pattern seen in leaves and absorbent roots after irradiation may have common points with the results obtained for differentiation of irradiated nodal segments. In both cases leaves respond to radiation similarly, independently of the developmental stage when the treatment was applied - before or after leaf differentiation. The aerial part differentiation of nodal segments was significantly less sensible to radiation than root differentiation.

\section{ACKNOWLEDGMENTS}

This paper is dedicated to the memory of Dr. Carlos Chagas Filho. Financial support: CNPq, CAPES, Fundação Universitária José Bonifácio, FAPERJ.

\section{RESUMO}

A capacidade de Ipomoea batatas diferenciar parte aérea e raízes foi avaliada após irradiação com raios gama. A diferenciação da parte aérea foi menos sensível que a das raízes. Contudo, na dose de 90 Gy nenhum broto diferenciado regenerou planta, enquanto $76 \%$ das raízes diferenciadas dos segmentos nodais irradiados manteve o crescimento. A radiação também induziu mudanças no perfil elotroforético de isoperoxidases. Plantas originadas de raízes tuberosas irradiadas apresentaram alteração no perfil de isoperoxidases foliares semelhantes ao perfil de folhas diretamente irradiadas. O perfil de isoperoxidases de raízes absorventes irradiadas diretamente não apresentou o mesmo padrão do perfil das raízes absorventes desenvolvidas de raízes tuberosas irradiadas.

\section{REFERENCES}

Acosta, M.; Arnao, M. B.; del Río, J.A. and GarcíaCánovas (1989), Kinetic characterization of the inactivation process of two peroxidase isoenzymes in the oxidation of indolyl-3-acetic acid. Biochim. Biophys. Acta, 996,7-12.

Alconero, R.; Santiago, A. G.; Morales, F. and Rodriguez, F. (1975), Meristem tip cultures and virus indexing of sweet potatoes. Phytopatology, 65, 769-773.
Barabas, K. N.; Szegletes, Z.; Pestenacz, A.; Fulop, K. and Erdei, L. (1998), Effects of excess UV-B irradiation on the antioxidant defence mechanism in wheat (Triticum aestivum L.) seedlings. J. Plant. Physiol., 153 : (1/2), 146-153.

Birecka, H.; Briber, K. A. and Catafalmo, J. L. (1973), Comparative studies on tobacco pith and sweet potato root isoperoxidases in relation to injury, indolacetic acid, and ethylene effects. Plant Physiol., 52, 43-49.

Birecka, H. and Catafalmo, J. (1975), Cell isoperoxidases in sweet potato plants in relation to mechanical injury and ethylene. Plant Physiol., 57, 74-79.

Coppens, L. and Dewitte, D. (1990), Esterase and peroxidase zymograms from barley (Hordeum vulgare L.) callus as a biochemical marker system of embryogenesis. Plant Science, 67, 97-105.

Fields, M. A.; Gaudreault, P. R. and Tyson, H. (1989), Heritable changes in ellectrophoretic properties of flax peroxidases resulting from variation in $\mathrm{N}$ nutrient level. Genetica, 78 : (2), 81-89.

Gazarian, I. G.; Lagrimini, L. M.; Mellon, F. A.; Naldrett, M. J.; Ashby, G. A. and Thorneley, R. N. F. (1998), Identification of akatolyl hydroperoxide and its role in the peroxidase-catalysed oxidation of indol3-yl acetic acid. Biochemical J., 333, 223-232.

Glaston, A. W.; Bonner, J. and Baker, R. S. (1953), Flavoprotein and peroxidase as components of the indolacetic acid oxidase system of peas. Arch. Biochem. Biophys., 42, 456-470.

Gordon, S. A. (1957), The effects of ionizing radiation on plants: biochemical and physiological aspects. Quart. Rev. Biol., 32, 3-14.

Hadrami, I. E.; Carron, M. P. and d'Ausac, J. (1989), Variabilité clonale du potentiek embriogène chez. Hevea brasiliensis; relation avec les polyamines (PA) et les peroxydases (PO) des cals. C. R. Acad. Sci. Paris, 308 : (serie III), 299-305.

Hokkinakis, D. M. and Brooks, J. L. (1979), Hydrogen peroxide-mediated oxidation of indole-3-acetic acid by tomato peroxidase and molecular oxygen. Plant Physiol., 64, 220-223.

Joersbo, M.; Andersen, J. M.; Okkels, F. T. and Rajagopal, R. (1989), Isoperoxidases as markers of somatic embryogenesis in carrot cell suspension cultures. Physiol. Plant., 76, 10-16.

Kenten, R. H. (1955), The oxidation of indolyl-3-acetic acid by waxpod bean root sap and peroxidase systems. Biochem. J., 59, 110.

Kubo, A.; Aono, M.; Nakajima, N.; Saji, H.; Tanaka, K. and Kondo, N. (1999), Differential responses in activity of antioxidant enzymes to different environmental stresses in Arabidopsis taliana. $J$. Plant. Res., 112 : (1107), 279-290. 
Lage, C. L. S. and Esquibel, M. A. (1992), Developmental changes induced by gamma irradiation in Ipomoea batatas L. Lam (sweet potato). Radiat. Res., 132, 237-241.

Lage, C. L. S. and Esquibel, M. A. (1995), Role of non enzymatic synthesis of indole-3-acetic acid in the Ipomoea batatas L.Lam. (sweet potato) response to gamma radiation. Arq. Biol. Tecnol., 38 : (4), 11731180.

Lage, C. L. S. and Esquibel, M. A. (1997), Growth stimulation produced by methylene blue treatment in sweet potato. Plant. Cell. Tissue and Organ. Cult., 48, 77-81.

Lage, C. L. S. and Rocha, H. (1994), Mild heat treatment as an agent of genetic assimilation in Drosophyla. Arq. Biol. Tecnol., 37 : (1), 65-76.

Larkin, P. J. and Scrowcroft, W. R. (1981), Somaclonal variation - a novel source of variability from cell cultures for plant improvement. Theor. Appl. Genet., 60, 197-214.

Luthra, Y. P.; Gandhi, S. K.; Joshi, U. N. and Arora, S. K. (1988), Total phenols and their oxidative enzymes in sorghum leaves resistant and susceptible to Ramulispora sorghicola Haris. Acta Phitopatol. Entomol. Hung., 23 : (3/4), 393-399.

Miura, K.; Hashimoto, T. and Yamaguchi, H. (1974), Effect of gamma radiation on cell elongation and auxin level in Avena coleoptiles. Radiat. Bot., 14, 207-215.

Momiyama, M.; Koshiba, T.; Furukawa, K.; Kamiya, Y. and Satô, M. (1999), Effects of gamma irradiation on elongation and indole-3-acetic acid level of maize (Zea mays) coleoptiles. Environ. Exp. Bot., 41 : (2), 131-143.

Murashige, T. and Skoog, F. (1962), A revised medium for rapid growth and bioassays with tobacco tissue cultures. Physiol. Plant., 15, 473-497.

Pressey, R. (1990), Anions activate the oxidation of indolacetic acid by peroxidases from tomato and other sources. Plant Physiol., 93, 798-804.
Reuveni, R.; Shimoni, M.; Karchi, Z. and Kuc, J. (1992), Peroxidase activity as a biochemical marker for resistance of muskmelon (Cucumis melo) to Pseudoperonospora cubensis. Phytopathology, 82, 749-753.

Riedle-Bauer, M. (19--), Role of reactive oxigen species and antioxidant enzymes in systemic virus infections of plants. J Phytopathol., 148 : (5), 297-302.

Scandalios, J. G. (1969), Genetic control of multiple molecular forms of enzymes in plants. A. Rewiel Biochem. Genet., 3, 37-79.

Skoog, F. (1934), The effect of X-ray on growth substance and plant growth. Science, 79, 256.

Skoog, F. (1935), The effect of X-irradiation on auxin and plant growth. J. Cell. Comp. Physiol., 7, 227-270.

Steeves, T. A. and Sussex, I. M., (1990a), Organogenesis in the shoot: determination of leaves and branches. In - Patterns of plant development. 2. ed. Cambridge University Press. pp 124-146.

Steeves, T. A. and Sussex, I. M., (1990b), Root branching. In - Patterns of plant developmen". 2. ed. Cambridge University Press. pp 245-247.

Van Huystee, R. B. (1987), Progress and prospects in the use of peroxidase to study cell development. Phytochemistry, 21, 1843-1847.

Van Huystee, R. B. and Clarins, W. L. (1982), Some molecular aspects of plant peroxidase biosynthetic studies. Ann. Rev. Plant Physiol., 38, 205-219.

Waddington, C. H. (1975), The evolution of an evolutionist. Cornell University Press. Ithaca, New York, USA. 